\title{
ESTUDOS RBE?
}

\section{Reinterpretando conceitos cristalizados com os professores: um degrau prévio para enfrentar os dilemas profissionais docentes}

Maria Helena G. Frem Dias-da-Silva

\section{Resumo}

Discute questões relativas às séries finais do ensino fundamental e trata de resultados de uma pesquisa colaborativa universidade-escola, visando fomentar o desenvolvimento profissional dos professores. A pesquisa foi realizada em escola pública do interior do Estado de São Paulo. Visando refletir sobre as contradições e os dilemas presentes no dia a dia dos professores, procurou-se analisar com os docentes, ao longo dos períodos letivos, alternativas pedagógicas viáveis em seu contexto de trabalho. Situações foram levantadas e analisadas, e o trabalho mostrou a importância de se considerar e, ao mesmo tempo, analisar colaborativamente a sabedoria docente com os professores e problematizá-la, incluindo contribuições teóricas e de pesquisa. Estes são passos imprescindíveis para enfrentar os dilemas profissionais docentes e transformar práticas. Fundamental é repensar em processo, repensar em contexto.

Palavras-chave: ensino fundamental; professor; saber docente; $5^{\mathrm{a}}$ à $8^{a}$ série; metodologia de pesquisa colaborativa 


\section{Abstract \\ Reinterpreting crystallized concepts with teachers: a first step to deal with the teaching dilemmas}

The article discusses questions related to the elementary school final years as well as the results of a collaborative research university-school in order to boost the teachers professional development. The research took place in a São Paulo State public school. Aiming at the teachers daily basis dilemmas, one analyzed the pedagogical choices and viable alternatives concerning their work context. Situations were analyzed and it showed the importance to consider and, at the same time, to analyze, in a collaborative way, the teacher knowledge and to problematize it including theoretical and research contributions. These are fundamental steps to combat the teacher professional dilemmas and to transform their practice. It is fundamental to rethink the process, rethink within context.

Keywords: Elementary School; teacher; teacher knowledge; collaborative research methodology.

Parece inequívoco que o final do século 20 ressignificou o papel de professores e escolas para a construção de projetos educativos, ocupando lugar estratégico nas reformas contemporâneas para transformação dos sistemas educacionais. Diversamente à racionalidade técnica, estamos a construir um arsenal teórico que viabiliza interpretar e ressignificar a vida e o trabalho dos professores, implicando uma concepção mais consequente e humanizadora, que os reconhece como intelectualmente hábeis e competentes para analisar a realidade e recriar alternativas de ação político-pedagógica (Nóvoa, 1991, 1992a; Gimeno Sacristán, 1991; Fullan, Hargreaves, 1992; Zeichner, 1993; Elliot, 1998; Giroux, 1997 - entre outros).

No Brasil, muitos foram os estudos que revelaram a presença de ensino verbalista, mnemônico e acrítico nas salas de aula das escolas públicas e subliminarmente apontavam os professores como peças-chave na perpetuação da mediocridade pedagógica, ou explicitamente atribuíram forte parcela de "culpa" à incompetência e ineficiente formação dos professores. Entretanto, nossa convivência profissional (e pessoal) com professores de ensino fundamental revela a existência de profissionais nem sempre bem-sucedidos, sentindo-se solitários e desmotivados, trabalhando segundo procedimentos tradicionais, ora cedendo às pressões da "pedagogia da facilidade", ora procurando se adaptar aos modismos educacionais, mas sempre convivendo traumaticamente com o fracasso e o desinteresse de seus alunos. 
Como sintetiza Nóvoa (1992b, p. 15),

[...] os anos 60 foram um período onde os professores foram ignorados, parecendo não terem existência própria enquanto fator determinante da dinâmica educativa; nos anos 70 os professores foram esmagados, sob o peso da acusação de contribuírem para a reprodução das desigualdades sociais; os anos 80 multiplicaram as instâncias de controle dos professores, em paralelo com o desenvolvimento de práticas institucionais de avaliação.

A valorização do trabalho docente se enriquece bastante com a tese da escola como locus de formação de seus profissionais e de construção de projetos educativos, permitindo o enfrentamento dos dilemas profissionais dos professores, por meio do desenvolvimento de uma praxis reflexiva que seria catalisada mediante o trabalho coletivo de seus membros. Essa formação centrada na escola pressupõe um "conceito ecológico de mudança" (Barroso, 1992), que possibilitaria identificar e analisar problemas e soluções do e para o cotidiano escolar, reconfigurando sua "dimensão institucional" (André, 1995).

A construção de um projeto político-pedagógico pelas escolas, antes de implicar exigência de reformas educacionais recentes, é uma proposta clássica para alguns educadores brasileiros (Azanha, 1987; Severino, 1991; Veiga, 1998, entre outros) que partilham a clareza da necessidade da intencionalidade e organização, fruto de reflexão e investigação, autocrítica e processo participativo para consecução dos objetivos humanizadores da educação, explicitando valores de um projeto social crítico e democrático voltado à realidade do Brasil, um País com índices inaceitáveis de distribuição de renda, com história de sociedade injusta e desigual, que - apesar dos indicadores sociais perversos - vem tentando se nortear pelo ideário neoliberal que aponta para uma globalização excludente (Frigotto, 1995).

Minhas pesquisas (Dias-da-Silva, 1994, 1997, 1998, entre outras) têm endossado a tese que reconhece o professor como sujeito de um fazer e de um saber, autor da prática pedagógica, que centraliza a elaboração crítica (ou acrítica) do saber na escola, mediatiza a relação do aluno com o sistema social, executa um trabalho prático permeado por significações - ainda que concretizado numa rotina fragmentada -, autor de um fazer docente que precisa ser respeitado em sua experiência e inteligência, em suas angústias e questionamentos, e compreendido em seus estereótipos e preconceitos, sujeito que deve ser reconhecido como desempenhando papel central em qualquer tentativa viável de revitalizar a escola (pública), pois que, se é sujeito, é capaz de transformar a realidade em que vive. E, se sujeito de um fazer, é também sujeito de um pensar; não é mero executor de técnicas ou tarefas impostas normativa ou acriticamente este, certamente, o grande equívoco da abordagem tecnicista.

Por outro lado, reconhecer e respeitar os professores não significa a legitimação a priori de princípios pragmaticamente partilhados nem pactuar com a hiper-responsabilização da escola. A busca do 
profissionalismo, o compromisso com o conhecimento historicamente acumulado e com a escolarização das camadas excluídas da escola pública, a construção de práticas pedagógicas includentes e a defesa de condições de trabalho justas - tendo como pano de fundo um projeto pedagógico crítico e democrático para nossa escola pública - são passos igualmente necessários para o desenvolvimento profissional dos professores.

Nesse sentido, o reconhecimento da "voz" dos professores (Giroux, 1997), da sua intelectualidade, implica também o refletir sobre ela: repensar (a si e seu trabalho), questionar, duvidar, contrapor argumentos e ideias cristalizadas. Como sugerem Fullan e Hargreaves (1992, p. 5),

O desenvolvimento do professor deve ouvir e apoiar a voz do professor: estabelecer oportunidades para os professores confrontarem os pressupostos e crenças que estão subjacentes às suas práticas; evitar modismos e implementações cegas de novas estratégias de ensino e criar uma comunidade de professores que discutem e desenvolvem seus propósitos juntos, ao longo do tempo.

Fundamental é repensar em processo, repensar em contexto. É imprescindível reconhecer que o desenvolvimento profissional docente não acontece apartado da cultura da escola, suas regras e ritos. É na escola que muitas concepções são perpetuadas; é numa escola concreta que os professores reforçam ou anulam saberes oriundos de sua formação. A escola tem ritmos próprios, normas e rotinas que condicionam a prática pedagógica, mesmo dos mais bem-sucedidos professores. Toda escola está condicionada por leis de um sistema escolar impactado pelas recentes reformas educativas que têm alterado o sistema educacional em vários países. E aprimorar o desenvolvimento profissional de professores implica necessariamente transformar esse cotidiano escolar.

Como adverte Elliot (1998, p. 143), "faz pouco sentido falar em desenvolvimento dos professores em contextos nos quais eles não podem livremente experimentar com suas práticas".

Ao considerarmos que o contexto real em que o professor trabalha e a cultura da escola presente em seu cotidiano são fatores decisivos para a construção de profissionais críticos e competentes, trabalhamos, durante quatro anos (1997-2000), com um grupo de professores de uma escola pública de II ciclo do ensino fundamental (de $5^{\mathrm{a}}$ a $8^{\mathrm{a}}$ série $)^{1}$ na periferia de cidade do interior do Estado de São Paulo/Brasil, mediante realização de pesquisa colaborativa universidade-escola pública, visando fomentar o desenvolvimento profissional dos professores e alicerçar transformações na escola. ${ }^{2}$ Apostando na quebra do isolamento do trabalho dos professores, mediante um tempo para reestruturar o pedagógico, e acreditando na importância do trabalho docente como fator decisivo para a transformação da escola, nossa equipe de pesquisadores (Marin et al., 2000) acompanhou, nesse período, o esforço desses professores visando repensar seu trabalho e elaborar um projeto pedagógico para duas escolas, uma das quais (de $5^{\mathrm{a}}$ a $8^{\mathrm{a}}$ série) é alvo desse paper, que sintetiza um dos subprojetos realizados.
${ }^{1}$ Mantem-se a nomenclatura série e numeração de $5^{\mathrm{a}}$ a $8^{\mathrm{a}}$ porque o estudo foi realizado antes do início da implantação dos nove anos no ensino fundamental.

2 Projeto "Desenvolvimento profissional docente e transformações na escola", financiado pelo Conselho Nacional de Desenvolvimento Científico e Tecnológico (CNPq) e pela Fundação de Amparo à Pesquisa do Estado de São Paulo (Fapesp) - Programa Melhoria do Ensino Público. 
Dando aos professores um papel de protagonistas da prática educativa, minha pesquisa, assumindo ensino como prática social, foi norteada pelo conceito de "sabedoria docente" (Dias-da-Silva, 1994), concebida como um saber não isomorfo ao senso-comum nem às teorias pedagógicas, que fundamentaria ações e concepções dos professores em seu trabalho docente cotidiano. Essa "sabedoria" dos professores - que se fundamenta nas experiências culturais, psicossociais e educacionais vivenciadas ao longo da vida - oferece-lhes confiança para trabalhar e norteia suas concepções e práticas de ensino. As pesquisas deixavam claro que esse saber muitas vezes implica equivocadas/falsas concepções e/ou concepções cristalizadas acerca de crenças, valores e procedimentos de ensino que poderiam explicar várias das diferenças entre o discurso e a prática dos professores.

Esse conceito se originou em tese de doutoramento na qual realizei uma pesquisa de natureza etnográfica com professores e classes de $5^{\text {a }}$ série do ensino fundamental. Os resultados (Dias-da-Silva, 1994, 1997) apontaram que boa parte das diferenças de atitudes e procedimentos que os professores especialistas (professores licenciados em Matemática, Língua ou Ciências) evidenciavam com seus alunos se fundamentava num saber-fazer cujas concepções se diferenciavam bastante das de seus colegas das séries iniciais.

Um parêntese se faz necessário: no Brasil, assim como em alguns outros países, as séries iniciais do ensino fundamental são assumidas por uma única professora, que durante todo o ano fica com um grupo de 40 crianças, ensinando todos os conteúdos escolares. A partir da $5^{a}$ série e até o final do ensino médio, os alunos passam a ser ensinados por um conjunto de professores, com formação especializada (universitária) para cada conteúdo curricular, em tempos diferentes ao longo da jornada escolar. É sempre importante lembrar que, no Brasil, apenas depois de 1970 foi criado o ensino de primeiro grau, que trazia consigo um enfoque diferente para a escola básica, que precisava ser democratizada, superando a visão ginasiana, que visava à formação das elites em busca do ensino superior (Spósito, 1984). Entretanto, a cultura de nossa escola preservou a "mentira pedagógica", como denunciava Azanha (1987): mesmo com uma escola fundamental de oito anos, vivemos sempre a "convivência sem integração", a "justaposição" de professores "primários" e "secundários", de crianças e adolescentes. Há uma diferença qualitativa que parece ter sempre se mantido subliminarmente no cotidiano de escolas e professores, que até hoje (30 anos após sua extinção na lei) ainda chamam as séries finais do ensino fundamental de "ginásio". Reproduzindo a fragmentação presente na própria concepção ginasiana, as (poucas) propostas que foram elaboradas vieram sempre desarticuladas a partir do ensino de cada conteúdo escolar que compõe sua estrutura. Assim, encontramos sempre documentos (ou mesmo pesquisas) sobre o ensino de História ou de Português ou Ciências, mas raros são os documentos-síntese sobre o conjunto das séries finais do ensino fundamental e seu papel. Apesar de sucessivas alterações de propostas curriculares, considero esse conjunto, 
da $5^{\mathrm{a}}$ à $8^{\mathrm{a}}$ série, um segmento de ensino para uma fase decisiva da construção do ser humano (a transição para a adolescência) que não tem clareza de sua identidade.

Sinteticamente, a tese mostra que esses professores especialistas - certos de que sua tarefa está centrada na "matéria" (subject-matter orientation) e não estão "lidando com crianças" - norteiam seu trabalho educativo por frágeis relações afetivas e comunicativas (incluindo poucas explicações táticas) com seus alunos, aliadas à rigidez nas exigências acadêmicas propostas (muitas vezes inconsistentes entre os vários professores), valorizando sobremaneira a independência dos alunos. Essa "sabedoria" dos professores especialistas foi sendo construída desde sua própria trajetória escolar (assim ele foi tratado por seus professores quando criança e, para ensinar X, tiveram sua formação na universidade) reforçada pela cultura da escola, que, além de fragmentar horários e conteúdos entre os professores (incluindo livro didático), também fomenta a "maternagem" pedagógica das professoras das séries iniciais, sempre mais afetivas e diretivas com as crianças, atitudes quase sempre criticadas pelos colegas das séries finais do ensino fundamental.

Entretanto, a convivência com classes de $5^{\mathrm{a}}$ série põe em xeque essa "sabedoria" que fundamenta o saber-fazer dos professores licenciados/ especialistas. Nessas classes, desnudam-se as contradições entre a realidade da sala de aula e seu saber fazer. A $5^{\mathrm{a}}$ série parece síntese dos dilemas cotidianos desses professores, talvez por isso seja a classe com a qual têm maior dificuldade em trabalhar.

As $5^{\text {as }}$ séries parecem sínteses dos dilemas cotidianos de seus professores, que envolvem algo muito mais enraizado que a alteração de procedimentos didáticos isolados. Dilemas porque implicariam também a alteração de seu saber sobre seu trabalho, a própria concepção de seu papel e de sua função na escola. Dilemas porque, mesmo reconhecendo que os alunos trazem "vícios" das séries anteriores, eles não podem (mais) ser tratados como crianças dependentes e nem há tempo para repor a "base" pressuposta. Dilemas porque, mesmo criticando a organização didática imposta pela escola, os professores precisam manter o ritmo e a quantidade de matéria [...] Dilemas porque confrontam o papel e a função atribuídos ao professor - seu saber fazer - com sinais que a realidade lhe impõe. Muitas vezes, afirmar um implica negar o outro. (Dias-da-Silva, 1997, p. 124-125).

Por outro lado, não há como negar a existência da ruptura na $5^{a}$ série, pois esta representa passagem na escola e fora dela - a própria faixa etária dos alunos revela a transição. Em vários países do mundo há ruptura no primeiro grau. Há "primário" e "ginásio" em sistemas e culturas tão diferentes como os/as da Hungria, da França ou do Chile. Mesmo os Estados Unidos, que admitem várias composições de escola elementar (incluindo separação das middle schools com quatro ou dois anos de duração), também não conseguiram superar a ruptura que muitas vezes é apenas antecipada na passagem da $3^{\mathrm{a}}$ para a $4^{\mathrm{a}}$ série. Parece que o sonho da integração harmônica e da continuidade processual no primeiro grau é desejo pedagógico partilhado. 
Um psicoterapeuta brasileiro, reforçando a ideia da ruptura, chegou a cunhar a expressão "síndrome da $5^{a}$ série" (Tiba, 1996) para se referir a essa fase de desenvolvimento da adolescência (na faixa dos 11 anos), que implicaria, entre outras, "alterações psicopedagógicas" da $4^{\mathrm{a}}$ para a $5^{\mathrm{a}}$ série e queixas de tonturas, mal-estar e dores entre as meninas e dificuldade de concentração e organização entre os meninos, que podem tender a se isolar ("estar no mundo da lua") ou a provocar os colegas e não parar quieto ("falar mais do que a boca") - essa uma das maiores queixas dos professores.

Todo esse contexto certamente acirra os dilemas dos professores das séries finais do ensino fundamental, mas, como interpreta Gimeno Sacristán (1992, p. 87),

[...] a atuação do professor não consiste em solucionar problemas como se fossem nós-cegos que, uma vez solucionados, desaparecem... o cerne do processo educativo reside na escolha de modelos de desenvolvimento humano, na opção entre diversas respostas face às características dos grupos e aos contextos sociais: o professor é um gestor de dilemas.

Gerenciar seus dilemas, lidar com eles, enfrentar as dificuldades certamente são aspectos centrais para o desenvolvimento profissional dos professores. Entretanto, se há uma "sabedoria" norteando e justificando as práticas cotidianas desses professores, a sua negação (ou crítica) mediante rótulos depreciativos acerca de seu trabalho e de sua concepção de ensino em nada alteraria seu trabalho. Ressignificar os alunos e essas classes e o ensino na $5^{\text {a }}$ série era aspecto decisivo para o enfrentamento dos dilemas desses professores, um processo de ressignificação que pressuponha ao mesmo tempo o respeito à experiência e voz dos professores e o questionamento de suas concepções cristalizadas, valorizando o conhecimento educacional acumulado.

Ou seja, se interpreto que a "sabedoria docente" desses professores "secundários" condiciona sua prática pedagógica, talvez aí resida a fragilidade da eficácia da imposição de "pacotes pedagógicos" para professores. Provavelmente a prescrição (ou imposição) de modalidades alternativas de ação (procedimentos ou materiais didáticos) para o professor não é adequada para diminuir sua impotência ou viabilizar mudanças em sua prática pedagógica. Como alertaram Sanders e McCutcheon (1986), os professores analisam informações ou instruções (novas) interpretando-as a partir das teorias que dominam, do saber de que dispõem, e só alteram suas ações caso o dado novo não seja incoerente ou contraditório com seu referencial e traga consequências muito desejáveis para seu trabalho.

Ainda que minha pesquisa anterior tenha deixado claro que muitos procedimentos empregados pelos professores da $5^{\mathrm{a}}$ série eram inadequados ou estéreis para promoção da aprendizagem dos alunos (incluindo desde a ausência de feed-back à tarefa ou realização de uma chamada apenas disciplinadora até a falta de estratégias para desenvolvimento de habilidades de raciocínio ou linguagem nos discentes), acredito que o caminho para a transformação implica necessariamente 
reconhecer e respeitar o professor como sujeito de seu trabalho, como autor de sua prática docente. O reconhecimento e o respeito pelo saber-fazer dos professores é pressuposto indiscutível em qualquer tentativa consequente de transformar a escola. Mais que isso, é condição para que a transformação ocorra - uma vez que o professor só altera seu fazer se não negar seu papel, só altera seu fazer se fizer uma nova leitura de seus fundamentos, seu saber.

Assim, hipotetizando que qualquer tentativa de intervenção na escola, sobretudo nessa série, precisava incluir um questionamento consequente sobre a ruptura com as séries iniciais, as práticas pedagógicas cotidianas e as concepções dos professores sobre o seu fazer docente, desenvolvemos uma pesquisa colaborativa procurando pensar com os professores formas de superação da ruptura, que pudessem reverter os índices de fracasso escolar da $5^{\mathrm{a}}$ série e/ou ressignificar essa série para que os professores se sentissem aptos a investir diferenciada e construtivamente em seu trabalho docente. Este texto sintetiza um caminho que foi sendo trilhado com e por um grupo de 20 professores de $5^{\mathrm{a}}$ a $8^{\mathrm{a}}$ série, de diferentes disciplinas, formação e tempo de experiência, que se debruçaram sobre seus dilemas profissionais, problematizando-os, para tentar construir alternativas de ação didática para seu enfrentamento.

O trabalho incluiu encontros semanais com esses professores (a maioria professoras), com diversificada experiência e formação, que lecionam as diversas disciplinas que compõem a grade curricular da segunda fase do ensino fundamental (Língua Portuguesa, Ciências, Matemática, História, Geografia, Educação Artística e Educação Física), originalmente sediados em uma escola pública de ciclo II (middle school) que atende cerca de 900 alunos de $5^{\mathrm{a}}$ a $8^{\mathrm{a}}$ série, oriundos das camadas populares, em bairro periférico de cidade do interior paulista.

Visando refletir sobre as contradições e os dilemas presentes no dia a dia dos professores, tendo como pano de fundo um projeto pedagógico crítico e democrático para nossa escola pública, procuramos também analisar com os professores, ao longo desse período, as alternativas viáveis no contexto de trabalho precarizado a que eles são submetidos nas escolas públicas brasileiras.

Durante os anos iniciais, realizamos as fases de sensibilização e diagnóstico que se seguiram à fase de problematização da prática pedagógica (detalhes metodológicos estão em Marin et al., 2000), num longo processo de reflexão e análise que incluiu desde as condições de trabalho a que os professores são submetidos na escola pública até suas representações sobre o papel da escola e do ensino. Recorrendo a variados procedimentos, discutimos desde critérios para avaliação do aluno até procedimentos de ensino e tipos de livro didático.

Num momento final, tomando especificamente a $5^{\mathrm{a}}$ série como alvo de reflexão, analisamos e discutimos com os professores, durante alguns meses, suas dificuldades, os problemas de ensino e alguns aspectos de sua "sabedoria" com essa série, investigando: 
- A memória escolar dos professores - Análise de relatos autobiográficos escritos de suas memórias educativas, com destaque para suas experiências de quando alunos da $5^{\mathrm{a}}$ série, os discursos e as atitudes de suas famílias e de seus professores.

- A voz dos alunos - Análise de respostas que os alunos (de todas as séries) daquela escola forneceram durante entrevista sobre suas experiências na $5^{\mathrm{a}}$ série: seus medos, sucessos e falhas e as atitudes e falas de seus pais, colegas, professores e diretores. Também foram analisadas redações sobre o tema, solicitadas por algumas professoras.

- A voz das professoras primárias - Análise de reunião ocorrida entre elas e suas colegas das séries iniciais, aliada à análise de depoimentos fornecidos pelas professoras primárias em redação na qual lhes foi solicitada uma análise crítica sobre o trabalho docente nas séries finais do ensino fundamental.

- As pesquisas sobre o cotidiano escolar - Entre outras, destaca-se a análise do livro que se originou da tese de doutorado da autora (Dias-da-Silva, 1997), um estudo de natureza etnográfica em classes de $5^{\mathrm{a}}$ série, com destaque para as situações de rotina escolar, reuniões e depoimentos dos professores.

A seguir, sintetizamos alguns dos principais aspectos analisados e discutidos em cada um desses momentos, que foram decisivos para repensar a "sabedoria" desses professores, problematizando seus dilemas com essas séries.

\section{A memória escolar dos professores}

A análise da memória educativa ${ }^{3}$ dos professores parceiros no projeto revelou que o aluno que eles foram está distante do perfil idealizado de "bom aluno" que a maioria dos professores preconiza (inclusive eles próprios).

São lembranças intensas, emocionadas, semelhantes às de uma grande maioria de cidadãos brasileiros não oriundos de camadas economicamente privilegiadas, que estudaram em escolas públicas e muitas vezes optaram pelo ensino noturno na maturidade, acumulando trabalho e estudo.

A maior parte dos relatos revela que nessa fase do "ginásio" eles foram um tipo de aluno "que não tinha consciência da importância da

${ }^{3}$ Exercício de reflexão que os professores realizaram buscando fragmentos de sua memória que pudessem reconstruir seletivamente o conteúdo educativo vivido por eles enquanto alunos, recuperando seu processo de formação. Esse exercício foi realizado individualmente pelos professores, resultando na produção de textos originais e autobiográficos bastante ricos e completos. escola", "nunca [foi] de estudar" ou "não lia, só gostava da televisão". Ou como escreveu um professor: "a melhor coisa da escola era o recreio e a saída".

Aparecem claramente os comportamentos típicos da adolescência, que vão desde a "timidez" ou "vergonha" em se expor ou o incômodo em ser "chamado à atenção" pelos professores até a cumplicidade com o(s) grupo/colegas ou as aventuras coletivas para afrontar as regras dos adultos na escola. Vários deles relatam que "colavam" nas provas, "repetiram de ano" ou "se recusavam a fazer o que os professores pediam". 
Apenas duas em 20 professoras registram ter vivido uma história escolar totalmente voltada para a vida acadêmica, com o clássico perfil da aluna nota 10 !

Todos apontam a presença de bons e grandes professores em sua trajetória escolar, que marcaram positivamente sua confiança na educação e até mesmo sua opção profissional pelo magistério e/ou pela área de conhecimento. Mereceram destaque suas professoras primárias, lembradas sempre com grande carga afetiva.

A lembrança dos bons professores confirma as características de professor bem sucedido apontadas na literatura (Cunha, 1989): são profissionais que dominam o conteúdo e metodologia de ensino: "gostavam do que faziam", "sabia explicar bem", "competente e muito exigente", "me ensinou a estudar sem decorar", "se preocupava com os resultados, se a gente tinha aprendido", "foi ele que me ensinou a pensar". A interação deles com os alunos também aparece como traço decisivo do sucesso pedagógico: "ele demonstrava carinho pela classe", "não resolvia nada no grito, tudo era com muita conversa". Aparecem muitas vezes referências a "paciência", ao "amor", a "dedicação", a "amizade", a "confiança" e ao "respeito". O sinal mais forte: "o que aprendi com ela jamais esqueci".

Entretanto (e infelizmente), a memória deles registra que os bem-sucedidos foram exceções - a grande maioria de seus professores foi considerada displicente ou agressiva, desinteressada ou incompetente, ou, o que é pior, "nem lembro de quem foram e o que faziam". Há lembrança de "vozes irritantes", "atitudes ríspidas", "fisionomias cansadas", "gritos insuportáveis", "desânimo total". Há marcas profundas de mágoas oriundas de "humilhações" impostas quer pela condição econômica quer por características acadêmicas dos alunos. Como sintetiza um relato: "o professor era uma figura que possuía um poder de punição muito grande, a gente sabia que ele podia nos humilhar a qualquer momento".

Curiosa e perigosamente, nenhum deles se lamenta da ausência do conhecimento e domínio de alguns conteúdos específicos que possa ser associada ao mau ensino que tiveram. É como se todos os relatos considerassem "natural" que a maioria dos professores tenham sido insignificantes ou pouco competentes.

Mas há muita nostalgia advinda da lembrança dos jogos, das competições, das festas juninas, dos desfiles cívicos, do coral, dos livros infanto-juvenis, das exposições e dos desenhos. Momentos de partilha, criação e orgulho escolar.

Quando provocados a relembrar especificamente sua passagem da $4^{\mathrm{a}}$ para a $5^{a}$ série, ${ }^{4}$ quase todos evocam reações de "euforia", "empolgação", "expectativas" e "ansiedade" por uma mudança que foi positivamente avaliada por todos eles:

Foi uma festa! Achava que eu já era "mocinha"! Levava o material nas mãos, não usava mais a mala, pois era mais bonito e me sentia mais adulta.

\footnotetext{
${ }^{4}$ A grande maioria dos professores estudou já sob o impacto da Lei n 5.692/71. Apenas duas fizeram o "ginásio".
} 
Adorei! A impressão que tinha é que estava crescendo, a ideia de vários professores me fascinava - muitos livros, muitos cadernos, escrever só com caneta, classe mista, carteiras dispostas em U, era o máximo!

Essa fase marca na memória educativa dos professores o papel dos conhecimentos específicos, que começam a ser presença forte a partir dessa fase. Vários depoimentos relacionam diretamente a passagem para a $5^{\text {a }}$ série à separação/discriminação específica dos conteúdos escolares, por exemplo: "comecei a perceber que gostava mais de uma matéria que de outras". As novas "matérias" e "responsabilidades" parecem ter atraído esses jovens alunos que passam a "desenvolver mais [seu] interesse em estudar" e até adquirir em casa "o direito de reclamar porque tinha que estudar duas ou três matérias no mesmo dia depois das aulas".

Os versos de uma professora sintetizam bem essa avaliação idealizada:

Deixamos um professor,

para enfrentar uma porção

Uns mais queridos,

outros não

dependendo da série,

do assunto ou da lunação

gostava de todas as disciplinas

sem discriminação.

Problematizar e discutir essa idealização da $5^{a}$ série e - ao mesmo tempo - o papel docente foi processo importante e decisivo.

\section{A voz dos alunos}

A acuidade de observação e análise dos alunos sobre a escola e a crítica aguda que eles verbalizam sobre o cotidiano escolar são elementos decisivos para o repensar da escola.

As manifestações dos educandos são realistas, acuradas, principalmente quando eles se pronunciam sobre "o que não anda bem na escola" e sobre a visão de "como a escola deveria ser"... Todos eles demonstram em sua expressão senso crítico em relação à análise da escola e, além de um desejo de que a escola se torne melhor, apresentam sugestões para que isso aconteça. (São Paulo. SME, 1991).

Com essa preocupação, aliada à necessidade de problematizar a prática pedagógica dos professores, incluindo a contribuição que os alunos devem trazer para um projeto pedagógico democrático e includente, fomos ouvir o alunado dessa escola. Um roteiro de entrevista (denso) foi elaborado para alunos das séries finais e ele incluía desde o papel da escola até as disciplinas favoritas e sugestões para sua melhoria. Após testadas, essas entrevistas foram realizadas por duplas de bolsistas de Iniciação Científica (do CNPq) com 10\% do alunado da escola, sorteados aleatoriamente representando séries e períodos, durante o $2^{\circ}$ semestre 
do ano letivo de 1997. Na escola de $5^{\mathrm{a}}$ a $8^{\mathrm{a}}$ série foram entrevistados 26 alunos de $5^{\text {a }}$ série (sendo 4 meninas), 23 da $6^{a}$ série (13 meninas), 18 de $7^{\text {a }}$ série ( 8 meninas) e 13 de $8^{\text {a }}$ série (incluindo 5 meninas), totalizando 80 entrevistados.

O relato dos adolescentes sorteados confirma resultados de pesquisas anteriores, que apontam a acuidade de percepção didática dos adolescentes ao criticarem um ensino verbalista, descontextualizado e autoritário. Entretanto, a grande maioria afirma que "gosta da escola" e considera sua importância, sugerindo estratégias para sua melhoria.

Dada a amplitude da investigação junto aos alunos, registro aqui apenas resultados especificamente voltados ao foco (ruptura da $4^{a}$ para a $5^{a}$ série), que se destacaram no contexto da análise mais ampla sobre a escola como um todo (alvo de investigação e problematização com todos os professores do projeto), dados decisivos para fomentar a problematização do saber dos professores.

Quando questionados sobre quais as expectativas e opiniões que seus pais, colegas e professores emitem (ou expressaram) para eles na fase da transição da $4^{\mathrm{a}}$ para a $5^{\mathrm{a}}$ série, os dados são preocupantes: os alunos relatam que tanto pais e colegas quanto professores apontam sobretudo "dificuldades" que eles enfrentarão (ou enfrentariam) nas séries finais do ensino fundamental (principalmente na $5^{\mathrm{a}}$ ), que incluem desde a multiplicidade de professores e regras até a rigidez de tempo, cobrança de conteúdos e, sobretudo, nível de exigência muito alto:

Que tem que pegar firme, não pensar em nada, que se ficasse brincando e fazendo o que fazia na $4^{\mathrm{a}}$ série eu ia repetir.

Falavam que os professores eram bravos, que são chatos.

Falava que eu tinha que ficar esperta, que não tinha tempo pra fazer as coisas, que tinha que fazer rápido.

Merecem destaque os relatos dos adolescentes que revelam que as próprias professoras da $4^{a}$ série criavam um "halo negativo" (confirmando Dias-da-Silva, 1997):

A professora da $4^{\text {a }}$ falava que a $5^{\text {a }}$ ia ser mais difícil.

Falava que nós ia entrar no ginásio, ia ter mais professor, que as matéria ia ser mais difícil [sic].

As professoras falaram que os professores da $5^{\text {a }}$ ia ser mais rígido, que a matéria era mais puxada [sic].

E, o que é pior, vários alunos denunciam que ouviram opiniões e conselhos que distorcem a realidade, implicando muitas vezes falsas ameaças: "Falavam que todo mundo ia bater na gente", "que tem prova todo dia", "que eu não ia saber nada", "que não pode mais repetir de ano, que tem que saber tudo" e, mais grave ainda: "falavam que eu ia sofrer". 
As implicações dessas expectativas certamente são graves e precisam ser problematizadas entre os próprios professores e famílias, já que podem ser transformadas em profecias autorrealizadoras.

Entretanto, pelo menos para os alunos que permaneceram na escola, os mais velhos (cursando $6^{\mathrm{a}}, 7^{\mathrm{a}}$ e $8^{\mathrm{a}}$ séries), o cotidiano escolar acabou por desmentir as opiniões de pais e professores: "quiseram me colocar medo, mas não é nada daquilo", "eles falavam, mas eu não achei, era tudo mentira".

Dado preocupante é que, apesar da análise otimista dos colegas, essa pressão pode ser um elemento bastante perturbador, sobretudo nos primeiros meses da $5^{a}$ série, como diz uma aluna: "ficava pensando, será que a $5^{a}$ é um bicho de sete cabeças?"

Detalhamos, então, a análise das entrevistas de amostra do alunado de $5^{\mathrm{a}}$ série dessa escola: 26 alunos (14 meninas e 12 meninos) de diferentes classes, com idades variando de 11 a 14 anos (a maioria com pequena história de fracasso escolar). Essa análise específica procurava detectar diferenças nos discursos desses/as garotos/as com relação aos/às das séries mais adiantadas, bem como pistas para tentar compreender como eles/as percebem/vivenciam essa série escolar e seu desempenho.

Assim, ao analisarmos especificamente como os alunos de $5^{\text {a }}$ série avaliam seu cotidiano escolar e as razões que norteiam suas opiniões e expectativas acerca do sucesso escolar, a relevância do trabalho docente emergiu de maneira muito forte. Quando indagados sobre os motivos de sua preferência por alguma disciplina escolar (conteúdos), a grande maioria desses alunos (mais de 70\%) apontam o professor como fator decisivo para justificar tanto a preferência quanto a facilidade (e/ou dificuldade) em compreender os diferentes conteúdos escolares. Vale salientar que há grande dispersão nas preferências em si - alguns gostam mais de Português (ou da "dona de Português"), outros de Ciências, Geografia ou Educação Física. Entretanto, seja apontando uma ou outra disciplina, a avaliação dos alunos se volta à importância do professor e seu trabalho como determinante para que sua preferência ou facilidade se justifique.

Enquanto os alunos das séries mais adiantadas $\left(6^{\mathrm{a}}, 7^{\mathrm{a}}\right.$ e $\left.8^{\mathrm{a}}\right)$ justificavam suas preferências quer por características específicas do conteúdo em si (por exemplo, a abstração exigida por uma equação de primeiro grau ou análise sintática) quer por características pessoais do próprio aluno (exemplo, "não gosto de poesia", "não tô nem aí com o que as viagens marítimas dos portugueses"), os alunos de $5^{a}$ série, diversamente, focam no trabalho docente sua avaliação sobre sua própria aprendizagem: para gostar e se sair bem na escola são decisivas as aulas e a metodologia empregada:

Eu gosto de X porque a aula é boa! A professora explica bem! A aula dela é muito gostosa.

Eu gosto de Y porque a professora ajuda, né? Ela explica bem e tem paciência com os alunos. 
Eu não gosto de K porque a professora passa muita coisa pra copiar e não explica direito. A gente pede pra ela explicar de novo e ela não explica!

A dona de $\mathrm{X}$ pede trabalho que deu pro outro dia.

Eu não gosto de X porque a professora falta muito!

Destaque especial na importância que assume o trabalho docente para os alunos dessas séries é dado ao caráter afetivo/humanizador manifestado pelos professores na relação com esses alunos. Como sintetiza um garoto: "se os professores são legais, a matéria é legal!"

Eu não gosto de X e Y, elas falam muito alto! Ficam gritando com a gente! São chatas. Não gosto da matéria porque não gosto muito da professora, ela tá sempre brava, sempre reclama de tudo, diz que tá com dor de cabeça!

Eu gosto de K porque a professora ajuda bastante a gente, ela aceita brincadeira, ela gosta de mim.

Se o aluno tá com problema ela dá uma força, ela conversa com a gente, não fica ofendendo.

E quase sempre a interação professor-aluno impregna o procedimento didático:

Eu acho difícil X. Eu perguntei se era pra arrumar as frases ela falou: não sei, pega e faz!

Eu não gosto do professor $\mathrm{X}$, que quando eu pergunto uma coisa ele nem responde.

Ela tem paciência com a gente, explica até a gente entender.

A voz dos alunos revela claramente a prática pedagógica como elemento decisivo na construção do sucesso escolar na $5^{\text {a }}$ série. E mais: o caráter afetivo-humanizador do trabalho docente como peça-chave nesse processo. Acatar ou não essa voz foi tarefa decisiva na problematização com os professores, que muitas vezes se assustaram com as respostas de seus alunos.

Outra fonte de dados sobre a voz dos alunos adveio de redações solicitadas por alguns professores às classes de $5^{\mathrm{a}}$ série. A leitura e análise desses textos com os professores permitiu investigar se (e como) percebiam a ruptura com a $4^{\mathrm{a}}$ série.

Quando solicitados a se manifestar sobre semelhanças e diferenças entre as séries, alunos e alunas são unânimes em apontar a ruptura, e alguns se referem à $5^{\mathrm{a}}$ como sendo (mais de 30 anos após sua extinção) o "ginásio".

Apesar da simplicidade e objetividade das respostas, os alunos destacam sobretudo a diversidade de professores e disciplinas e a agitação da classe como os grandes diferenciadores entre as séries. Vale lembrar que eles se dividem em suas preferências - pela $4^{\mathrm{a}}$ ou pela $5^{\mathrm{a}}$ série. Não pudemos detectar tendência clara nesse aspecto. 
Entretanto, todos destacam que o número diferenciado de professores implica/inclui a introdução de novas disciplinas (como Inglês e Educação Física), a multiplicidade de tarefas (que podem "confundir a cabeça") e o aumento da profundidade/dificuldade dos conteúdos como traços diferenciadores da $5^{a}$, sempre aliado à denúncia do empobrecimento da relação afetiva:

Na $4^{\mathrm{a}}$ nós estávamos aprendendo as mesmas coisas que aprendemos na $2^{\mathrm{a}} \mathrm{e}$ na $3^{\mathrm{a}}$, na $5^{\mathrm{a}}$ nós já estamos aprendendo coisas novas e bem mais diferentes.

A matéria da $5^{a}$ é mais importante que a da $4^{a}$, os professores da $5^{\text {a }}$ é mais importante. Na hora da explicação os professores são sérios e é muito mais forte [sic].

$\mathrm{Na} 4^{\mathrm{a}}$ as atividades não são tão forçadas como na $5^{\mathrm{a}}$, os exercícios não são difícil e na $4^{\mathrm{a}}$ é melhor porque só tem um professor e não um monte que às vezes dificultam muito nossas cabeças [sic].

A professora da $4^{\mathrm{a}}$ tem mais paciência pra ensinar quem quer aprender, dá pra gente aprender mais a matéria.

Já a "zoeira" ou "bagunça" da classe é apontada por praticamente todos os alunos como comportamentos diferenciadores da $5^{a}$ série, confirmando Tiba (1996):

Na $5^{\mathrm{a}}$ você conhece amigos muito loucos, você entra na fase da adolescência e pode bagunçar.

A $4^{\text {a }}$ é mais quieta e a $5^{a}$ não, é mais bagunceira, muita zoeira com as meninas.

$\mathrm{Na} 4^{\mathrm{a}}$ a gente se interessa mais pelos estudos e na $5^{\mathrm{a}}$ as pessoas pensam que só porque estão na $5^{\text {a }}$ são os maiores do mundo e ficam a aula inteira conversando e muitas vezes até faltam com respeito aos professores!

Apenas uma aluna apontou a organização da escola fragmentada em aulas e salas como geradora da indisciplina:

A $5^{a}$ é uma baderna quando sobe aula ou a classe fica de janela. Um professor quando falta fica aquela confusão! Prefiro a $4^{\text {a' }}$

Todos esses dados foram socializados com os professores, que coletivamente discutiram e analisaram suas concordâncias e divergências com as representações dos alunos, com a clareza de que elas eram aspecto decisivo para interpretar suas classes de $5^{a}$ série: "É quebrando a cultura do silêncio, ouvindo os educandos, discutindo com eles suas visões e estando abertos à reflexão e à ação que se pode caminhar efetivamente numa perspectiva de construção de uma escola pública democrática." (São Paulo. SME, 1991).

\section{A voz das professoras "primárias"}

Já desde os anos sessenta (ou sempre?), como magistralmente registra Pereira (1969), a relação entre as professoras das séries iniciais 
(eternamente chamadas "primárias") e as das séries finais ("secundárias") é permeada por preconceitos e acusações de ambas as partes. As diferenças de nível e tipo de formação dos professores, objetivos e modalidades de ensinar e mesmo (sobretudo) as formas de interagir com os alunos geram intermináveis discussões nas escolas. O mais grave é que entre "vocês são muito maternais" e "vocês é que são muito exigentes!" se colocam claramente as diferenças de "sabedoria" desses professores sem que esse saber docente seja problematizado (Dias-da-Silva, 1997). Quase sempre apenas aparecem como rótulos depreciativos por ambas as partes.

Ao analisar aspectos do cotidiano escolar que sinalizam claramente as diferenças de concepção e ação das professoras de $4^{\text {a }}$ série com os professores da $5^{a}$, já discuti em trabalho anterior (Dias-da-Silva, 1997, p. 112):

Parece evidente que o que está em jogo na passagem da $4^{a}$ para a $5^{a}$ série é muito mais que o número de professores ou disciplinas. Estão em jogo fazeres diferentes. Estão implicados saberes diversos, objetivos distintos, intenções e crenças...

Em síntese, poderíamos dizer que o trabalho do professor na $4^{\mathrm{a}}$ série parece se nortear por um nível alto de comunicação com as crianças, o que inclui até um excesso de explicações táticas. Há maior consistência nas condutas e flexibilidade na distribuição do tempo para as atividades propostas, porém maior rigidez nas cobranças. Parece que as professoras "primárias" atribuem pouca importância à independência das crianças, ocorrendo o inverso com a demonstração de afeto.

Já os professores de $5^{\mathrm{a}}$ série (na verdade, professores de $5^{\mathrm{a}}$ a $8^{\mathrm{a}}$ série) parecem se nortear por um nível rígido de exigências preestabelecidas pelo tempo, porém com poucas cobranças sistemáticas, muitas vezes inconsistentemente estabelecidas (a variação de atitudes didáticas entre os professores é significativa). Se por um lado a comunicação com a criança é permeada por poucas explicações, demonstrações de afeto, por outro, é grande o valor dado à independência do aluno.

[...] Discutir valorativamente as diferenças entre essas séries parece ser tão inconsequente quanto analisar se a infância é melhor que a adolescência...

Apesar da fragilidade do juízo de valor, a análise e a problematização dessas diferenças podem ser aspectos decisivos para enfrentar a ruptura existente no trabalho docente dos professores "especialistas", problematização que precisa reconhecer o saber docente tanto das professoras das séries iniciais ("primárias", rotuladas como PI, agora PEB I, pelo sistema escolar) quanto das séries finais ("secundárias", rotuladas como PIII ou PEB III) do ensino fundamental.

Assim, ainda que superficialmente, analiso aqui fragmentos do discurso das professoras primárias sobre as diferenças que percebem em seus colegas das séries finais que podem ser decisivas para a construção do sucesso escolar na $5^{a}$ série. Esse "discurso" foi objetivado por meio de duas fontes: a) redação de 14 professoras das séries iniciais provocadas pela pergunta "Diferenças e semelhanças entre as PI e as PIII?"; 
e b) manifestações das professoras em reunião conjunta realizada com os professores das duas escolas ( $1^{\mathrm{a}} / 4^{\mathrm{a}}$ e $5^{\mathrm{a}} / 8^{\mathrm{a}}$ séries), organizada pelas diretoras, para discussão da implantação da progressão continuada no ensino fundamental.

Em qualquer que seja a situação, as professoras primárias apontam unanimemente o aspecto afetivo-relacional do trabalho docente como a maior diferença que percebem entre elas e os professores "secundários" (ainda que sempre atenuada pela ausência de tempo de convivência dos colegas com os alunos):

O prof. I conhece mais seus alunos, convive mais tempo com eles, temos que conversar com ele quando tem algum problema.

O professor passa a ser confidente da criança, há mais carinho e aproximação entre eles, participa da vida do indivíduo fora da escola.

PI consegue compartilhar melhor com a criança o seu dia a dia.

É importante lembrar que várias delas não aceitam o rótulo depreciativo de maternagem, ressaltando que seus objetivos são diferenciados, o que implica fundamentos diferentes para seu trabalho docente nessas séries, confirmando Carvalho (1995):

O PI trabalha mais a parte afetiva e social do aluno, já o PIII mantém-se distante.

Dizem certos professores de $5^{\mathrm{a}}$ a $8^{\mathrm{a}}$ série que nós, professores de $1^{\mathrm{a}}$ a $4^{\mathrm{a}}$, somos muito maternais, mas isso faz parte de uma psicologia necessária a essa faixa etária.

Os PIII têm um certo distanciamento do professor I, acho que é até um certo preconceito, pois talvez esse nosso jeito "maternal" faça com que eles não nos vejam como profissionais que somos. Todos estudaram e, acredito, nos preparamos para exercer nossa função. Ninguém está aqui para "brincar"!

Vale destacar o registro de uma professora, que, com muita lucidez, aponta a importância da interação afetiva para o próprio desenvolvimento de habilidades escolares nos alunos - não se trata de "meramente amar a criança", como apontaram algumas pesquisas brasileiras:

Ao longo do trabalho de $1^{\mathrm{a}}$ a $4^{\mathrm{a}}$ série, têm os professores lidado com seres ingressantes na socialização. Tudo é mais paulatino nesse ingresso. Há que se escutar, há que se pacificar, há que se alfabetizar... Tudo num clima de "não fique nervoso", "logo você supera isso", "é preciso ter paciência para aprender também". E o aluno acaba se apegando afetivamente durante as quatro primeiras séries. Já nas séries finais, as aulas, com tempo determinado, impedem o professor de muitas "delongas" com o aluno, que tem que ser tratado de modo impessoal e prático para não ser alvo de brincadeiras maldosas dos próprios colegas.

A falta de tempo de convivência com os alunos, a estrutura escolar e a fragmentação dos conteúdos são aspectos apontados pela grande maioria 
dessas professoras quando analisam o trabalho dos professores das séries finais. Solidárias, percebem os entraves vividos por seus colegas:

O PIII dispõe de pouco tempo para estar com seus alunos, ele tem a função de aprofundar as noções, criar novos conhecimentos.

O trabalho do PIII não pode passar do conteúdo, da matéria, pois esta é muito extensa e o tempo é curto.

Porém, o maior incômodo das professoras "primárias" recai na acusação de incompetência, frequente nas falas de seus colegas "especialistas":

Os PIII já querem um aluno pronto, para cumprir um programa no decorrer do ano letivo, sem respeitar a nossa realidade, onde passam a nos ver como se fôssemos aprendizes e não profissionais.

O que me incomoda é quando o professor procura achar um culpado para o fracasso de seu aluno e sempre a culpa recai sobre o professor anterior. Às vezes fico aborrecida e até chego a pensar que sou incompetente.

Ironicamente, a implantação do regime de progressão continuada (a partir de 1998) acirrou a preocupação com a expectativa das acusações, que passa a incomodar toda a escola de $1^{\text {a }}$ a $4^{\text {a }}$ série, como sintetiza a diretora na reunião:

Estou muito preocupada porque não pode reprovar mais. Esses alunos que não têm condição de ir pra $5^{\mathrm{a}}$ série, não dá mais pra segurar! Vai ficar reprovando 3, 4 anos? Mas é importante ter integração entre as escolas, porque os professores não têm que questionar os professores anteriores e sim o que ele vai fazer! Eles têm 13, 14 anos e não podem permanecer na $4^{\text {a }}$ série!

E completa uma professora: "Diante desse sistema, estamos de mãos e pés atados. O que podemos fazer? Há uma pressão muito forte."

E a "pressão forte" implica o ingresso na $5^{\text {a }}$ série de alunos que, segundo as professoras da $4^{\mathrm{a}}$,

- não leem correntemente e não dominam ortografia;

- não conseguem aprender nem o mínimo necessário. Eles vêm da $2^{a}, 3^{a}$ série sem estar alfabetizados;

- não sabem tabuadas, não sabem as operações de dividir e o mecanismo de subtração, não sabem "transferir aprendizagem".

Num certo sentido, as professoras primárias se preocuparam em explicitar para as das séries finais que têm consciência de que o rendimento de alguns (ou muitos?) alunos não está de acordo com o que elas esperam nem com seu nível de exigência: "A gente sabe que o aluno não sai 'tinindo' como precisava, mas o atual sistema manda seguir em frente." Se por um lado o sistema pode ter oferecido às professoras um álibi que alivie as acusações do réu, por outro o "seguir em frente" manda que os professores das séries finais precisarão "se acostumar a receber os alunos do jeito que eles vêm". Como alerta uma professora: "O professor 
tem que ser elástico: ir e voltar! Talvez eles não tenham aprendido aqui, mas aprendem com vocês. Se eles não sabem, alguém tem que ensinar!"

Nesse universo de críticas recíprocas, vale salientar que nenhuma professora das séries iniciais percebeu (ou chegou a registrar) que seu trabalho possa ser também alvo de elogio ou reconhecimento por parte dos professores "secundários". Entretanto, quando provocados (durante discussões do projeto), vários professores das séries finais afirmaram que tinham com as PI uma "troca silenciosa", "só na observação", "não precisava falar", e que essa observação - mediante convivência que tinham na escola de $1^{\circ}$ grau, modelo anterior à reforma - permitia que eles percebessem que as professoras primárias "tinham muito mais proximidade com o aluno que [eles]", que "conseguiam fazer o aluno trabalhar, conheciam mais o aluno". E reconhecem: "[elas] sabem fazer muito mais coisas que nós, são mais criativas para elaborar atividades - sabem desenhar, fazer flores de papel"; "Organizar festas como elas? Ninguém!"

Infelizmente, esse reconhecimento não é percebido pelas professoras primárias, que denunciam o preconceito e a discriminação de que são alvo. Porém, essa problematização também implicou repensar para nossos professores.

\section{As pesquisas sobre o cotidiano escolar}

Ao longo dos meses, os encontros com os professores "secundários" foram permitindo que eles explicitassem suas principais dificuldades em lidar com as classes de $5^{a}$ série. Sejam acadêmicas, sejam comportamentais, as habilidades e condutas dos alunos iam se evidenciando claramente como fontes de dilemas de trabalho para esses professores, que progressivamente reconheciam: "mas eu não sei alfabetizar", "me irrito quando ficam perguntando quantas linhas pula", "não tenho saco com crianças", "eles falam todos ao mesmo tempo", "eu saio morta da classe!"

Buscando aprofundar o "questionamento consequente" (Dias-daSilva, 1997) sobre a ruptura, optamos por mediá-lo pelos resultados de pesquisas sobre cotidiano escolar (André, 1995). Ao analisar a "voz dos alunos" - que evidenciava seus medos e as falsas ameaças que ouvem a respeito da passagem para a $5^{a}$ série (Truzzi, Dias-da-Silva, 1998) e suas expectativas de relacionamento afetivo e humanizador com os professores (Mine, Dias-da-Silva, 1998) - ou discutir a avaliação que as professoras primárias fazem do trabalho pedagógico realizado nas séries finais (Carvalho, 1995), o grupo de professores foi compondo um quadro que implicou repensar os "óculos" com que eles interpretavam seu trabalho e seus alunos de $5^{a}$ série. Repensar sua "sabedoria docente", seu saber fazer.

Ao solicitar que os professores lessem o livro que resultou da pesquisa de tipo etnográfico que realizei em duas escolas públicas com 
as classes de $5^{a}$ série (Dias-da-Silva, 1997), confirmamos a hipótese de André (1994, p. 74):

Trazer cenas do cotidiano escolar analisadas em pesquisas do tipo etnográfico pode ser excelente alternativa para o exercício da tão buscada articulação teoria-prática... em que o professor estará olhando para uma espécie de espelho onde a imagem não é a sua, mas uma que a lembra de perto... e pode favorecer um olhar mais crítico e menos preconcebido sobre o trabalho docente e, quiçá, sobre o próprio trabalho.

Textos escritos pelos professores (relatórios parciais do projeto) revelam claramente que a leitura da pesquisa possibilitou esse questionamento autocrítico:

Quando li o livro, algumas vezes tive a sensação de estar fazendo parte dele: aquela sensação de "já vi esse filme". A impressão de que atitudes, ações e reações que às vezes achamos que são únicas, isoladas, se desfez. Paralelamente à leitura comecei a me observar mais e alterar atitudes que tinha. Atitudes que hoje fazem parte de um passado recente, mas passado.

Quando li o livro percebi que essas crianças quando agem, muitas vezes de forma que a gente pensa que vai enlouquecer com a atitude deles, o mais interessante é que nós não os entendemos, pois quando eles agem dessa maneira é justamente para dizer: "Ei! Eu estou aqui e quero aprender, e quero te mostrar o que eu sei!"

Após a leitura foi impossível o professor não rever o seu trabalho e fazer uma autoanálise do que tem feito com essas crianças, seus medos, inseguranças e ávidas de curiosidade e ansiedade em aprender. E quantas delas se decepcionaram com a escola, e quantos de nós somos responsáveis por isso?

Assim, a discussão de um projeto educativo pedagógico para a $5^{\mathrm{a}}$ série foi enraizada nos resultados das investigações sobre os próprios professores e seus alunos, que, aliados a leitura do livro, permitiram análises (interessantíssimas) que evidenciavam o questionamento da concepção cristalizada que os professores traziam sobre a "imaturidade" e "agitação" dos alunos ou seus preconceitos sobre o trabalho das professoras primárias. Vários estereótipos iam sendo checados, como, por exemplo, o incômodo dos professores com os chamados "vícios do primário" ou sua tendência em depreciar o conhecimento que os alunos trazem das séries iniciais. Acompanhamos evidências claras de alterações na concepção dos professores sobre seus alunos e seu próprio trabalho:

Ficou claro que um dos motivos do baixo índice de aprovação na $5^{\mathrm{a}}$ série é o fato de os professores serem incapazes de perceber as necessidades dessa fase. O que, no fundo, é meio verdadeiro: eu mesma não sei alfabetizar.

Conscientizei-me das dificuldades enfrentadas pelo aluno nessa fase de transição e da tarefa do professor em tornar esse momento menos angustiante. Sensibilizou-me para as dificuldades dos alunos. 
Se esse questionamento das concepções prévias e tomada de consciência das próprias dificuldades foi originado especificamente pela leitura das pesquisas ou pela análise dos depoimentos das crianças, ou de sua própria memória educativa, ou do repensar o papel da escola e a função docente no século 21, ou..., é impossível precisar. Mas é possível reconhecer: ao final desse processo, todos os professores, se percebendo diferentes, ressignificaram essas séries e seu trabalho - e coletivamente passaram a elaborar um projeto educativo diferençado para a $5^{\mathrm{a}}$ série.

\section{Considerações finais}

Sob minha ótica, essa alteração no saber docente sobre a prática pedagógica foi sendo construída ao longo de um processo que durou muitos meses e dificilmente pode ser creditada especificamente a uma atividade ou a um argumento. Nesse período, vários dos conceitos cristalizados na "sabedoria" do professor, construída ao longo de sua vida e carreira, foram sendo reinterpretados. Por meio de todas essas atividades e procedimentos, os professores puderam problematizar seu trabalho docente, explicitando seus dilemas profissionais: "O professor só altera seu fazer se não negar seu papel. Só altera seu fazer se fizer uma nova leitura de seus fundamentos, de seu saber" (Dias-da-Silva, 1997, p. 142).

Ao problematizar sua prática pedagógica, suas crenças e concepções sobre seu trabalho e seus alunos, esses professores fizeram uma nova leitura de seu cotidiano escolar. Como escreveu uma professora:

Minha visão em relação às crianças de $5^{a}$ série era um pouco preconceituosa. Primeiro porque eu os via como pelotão que já chegava correndo na sala, gritando alvoroçados, com uma energia infinita, e que estavam lá apenas para brincar. Segundo, porque como ensinaria a eles o funcionamento do sistema imunológico, por exemplo? Se para eu compreendê-lo demorou um semestre, e foi uma matéria cursada no último ano da Faculdade, momento em que já estava mais madura e que já dominava vários conceitos necessários para entendê-los, como iria fazer para entrar na cabeça dessas crianças conceitos como gânglios linfáticos ou células de memória? Acredito que os cursos da faculdade preparam o profissional, só que distante do cenário em que irá atuar. Dava a sensação de que a teoria não se aplica à prática.

Esses professores interpretaram de forma diferente seus alunos e os objetivos de seu próprio trabalho:

Eu entendi que $5^{\mathrm{a}}$ série é isso: diferente de qualquer outra, que também possui seus encantos e problemas. Nenhuma outra série desafia tanto o professor quanto esta. Ela testa sua paciência e sua formação. É o início de uma lenta transformação física e intelectual em que o ato de adolescer de uma nem sempre se dá paralelamente ao de outra. Ao lado do orgulho de ser "grande" e "importante" porque mudou de escola, passou para a turma do "ginásio", mostrando isso na prontidão para participar de todas as atividades propostas pela escola, o aluno de $5^{\mathrm{a}}$ série pede silenciosamente afeto, atenção, que seja valorizado, visto e ouvido. Uma pergunta sobre o conteúdo escolar tem o mesmo valor 
de perguntas do tipo "Posso virar a folha do caderno?", "Posso usar canetinha colorida?" Não é à toa que muitos professores fogem da $5^{\mathrm{a}}$ série como o diabo foge da cruz.

E porque pensaram/conceberam diferente, puderam ao mesmo tempo organizar e agir de forma didaticamente diversa. Como apontam alguns professores:

Como fazer essa passagem inevitável causando o menor impacto, ou melhor ainda, causando um impacto positivo? Pensamos que era necessário diminuir a ansiedade com que essas crianças chegam à escola, desfazer seus medos, valorizar seus conhecimentos e também mudar a imagem negativa que elas têm de nós, professores de $5^{\text {a }}$ série.

Cabe a nós, professores da $5^{a}$ série, a tarefa de desmistificá-la, e, para tanto, haveria que se criar uma ponte entre as diferentes formas de agir de cada profissional. O aluno que quero na $5^{a}$ série precisa ser construído, não negando em momento algum os conhecimentos acumulados nas séries iniciais. Se existe a ruptura, é preciso construir uma passagem, uma ponte.

Assim, só no último ano do projeto, aliando a riqueza de alternativas de procedimentos didáticos advindos da experiência dos professores com a clareza de objetivos e norte teórico-metodológico para construir alternativas de ação, os professores construíram coletivamente um conjunto de atividades e procedimentos para serem realizados no primeiro semestre de trabalho com classes de $5^{\mathrm{a}}$ série, que denominaram "procedimentos-ponte". Ponte que se iniciou com a apresentação de espaços e pessoas aos alunos ingressantes:

Partimos do princípio de que, já que essas crianças não conhecem nem ao menos o prédio, o espaço físico da escola, pensamos em uma caminhada que teria como ponto de partida a escola que elas frequentaram até a $4^{\mathrm{a}}$ série, seguido de um lanche na praça do bairro e uma caminhada até a "nova escola". Assim, pensamos em fazer uma passagem sem ruptura, uma "passagem simbólica"; essa caminhada seria uma ponte ligando as duas realidades - a passada e a presente.

Essa ponte implicou desde a elaboração de colagens e promoção de debates com os professores até a produção de um livro-síntese, produzido por cada aluno, com atividades propostas por todas as disciplinas e professores, incluindo desde a elaboração de um autorretrato até a construção de um terrário, desde organização de sua árvore genealógica até redação de poesias e relatórios:

Planejamos uma atividade que permitisse ao aluno "mostrar-se" como pessoa (identificação) e elevar sua autoestima, ao mesmo tempo em que apresentasse os conteúdos escolares e desse-lhes a devida importância no contexto da aprendizagem escolar. Pretendíamos também que essa atividade nos permitisse detectar dificuldades desse aluno e, ao mesmo tempo, perceber o que ele já sabe e do que é capaz. 
Mais que integrar atividades de todos os conteúdos dessa fase de escolarização, o "livrinho" permitiu que os professores reconhecessem esse aluno que lhes chega como sendo alguém capaz:

Eles falaram a verdade, foram sinceros em todas as disciplinas. Será que eu faria com tanta naturalidade ou melhor que eles? Porque nós fizemos a nossa "memória" e, muito provavelmente, maquiamos a nossa história. Não achei que a criatividade deles fosse tão grande, eles não só desenham, eles escrevem também!

Ao concretizarem procedimentos que transcendem a fragmentação do trabalho típica dessa série, reforçada pela separação disciplinar dos livros didáticos, os professores foram ressignificando a importância dos conteúdos escolares:

Foi através do meu primeiro livro que percebi que posso trabalhar diferentes atividades e que agora estou conseguindo entender e interpretar essas crianças. Ele me deu condições de dar um pulo grande profissionalmente: Satisfez meu ego! Pois vi a empolgação deles e senti que eu conseguia passar para eles o conceito de história, a importância de estudar História, e mostrar que nós somos parte da História. É muito bom para nós, professores, descobrir que está ocorrendo aprendizagem.

Houve total participação e satisfação por parte dos alunos. Percebemos sorrisos, olhos brilhando de felicidade. Resgatamos nessas crianças valores como autoestima, cooperação, organização, perseverança e, ao construir o terrário, eles se sentiram como cientistas, criadores!

É decisivo salientar que praticamente todos os professores se espantam ou se surpreendem quando percebem o interesse do aluno pelo conhecimento, o valor que atribuem a essa parcela de cultura - que é parte de seu componente curricular -, quase sempre rotinizada ou ensinada sem o encantamento que eles detectaram nos alunos.

O impacto positivo e a repercussão entusiasmada dessas atividades envolvendo um projeto com a $5^{\text {a }}$ série são indicadores claros de que talvez tenhamos enfrentado um "problema de fronteira" (Schlechty, Whitford, 1988) que nem Universidade nem escola conseguiriam resolver sozinhas.

E mais: o enfrentamento dessas dificuldades só se viabilizou porque mobilizou pensamento e ação dos professores - a alteração do fazer apenas se concretizou mediante questionamento do saber docente cristalizado na cultura escolar, saber que pode se beneficiar (e muito) das contribuições oriundas das pesquisas sobre o cotidiano escolar, que podem permitir aos professores uma releitura de seu saber fazer (André, 1994) orientada por um norte político e educacional claro. Problematizar com todos os professores dos vários componentes curriculares permitiu enfrentar a fragmentação e o isolamento que caracterizam seu trabalho (Sampaio, 1998), projetando um "saber pedagógico" mais geral independente de sua disciplina específica - e, fator decisivo, a alteração do trabalho docente como projeto coletivo, pressupondo planejamento e organização.

A efervescência de ideias sugeridas na elaboração do projeto coletivo, em discussões que planejaram formas diferenciadas de trabalho, foi 
decisiva para sua repercussão positiva - quer para o envolvimento dos alunos quer para o próprio desenvolvimento profissional dos professores. Esse repensar foi decisivo para aumentar o entusiasmo e a autoestima dos professores:

Normalmente os primeiros dias de aula sempre foram um martírio para os professores. Desta vez, a imagem foi de alegria, prazer, os professores estavam afetivos, a "escola parecia uma festa".

Foi uma satisfação enorme ver os colegas folheando as produções dos alunos com prazer, lendo os textos com interesse, emocionando-se, surpreendendo-se.

Como analisou Elliot (1998), "a pesquisa-ação requer que professores exercitem capacidades que somente podem ser desenvolvidas no contexto das práticas concebidas como experimentos inovadores". Ouso dizer que talvez o impacto mais interessante desse processo tenha sido o fato de os professores encararem sua própria resistência em, pensando diferente, fazerem algo que nunca tinham feito antes e lidarem com suas expectativas e medos de que "não desse certo":

\begin{abstract}
Sinto que, embora essas atividades tenham sido propostas por nosso grupo de professores, alguns colegas não pareciam confiar muito no sucesso delas. Posso dizer até que, por insegurança, pela novidade, por (talvez) ter de "dar cara para apanhar", alguns temiam essas atividades. Por tudo isso, seu resultado foi causando impacto. Os cartazes não só surpreenderam os professores pela criatividade, beleza plástica (desenhos, recortes, etc.), pela sinceridade na colocação de opiniões, pelos conhecimentos manifestos de conteúdos de várias disciplinas, pela clareza na exposição de ideias, pela manifestação de valores/atitudes positivas, e até mesmo pelos conhecimentos de língua materna, mas também checavam o enfoque que alguns professores ainda manifestavam, de que alunos de $5^{\mathrm{a}}$ série eram "indisciplinados" e "sem base".
\end{abstract}

Estou convencida de que essa experimentação de procedimentos alternativos, elaborados e executados coletivamente pelos professores, é estratégia decisiva para a mudança profissional docente com implicações diretas na transformação da escola: os professores (assim como tentam fazer com seus alunos) se vendo capazes, tentando e experimentando, enfrentando o risco do fracasso, sob uma perspectiva mais crítica e investigativa.

Entretanto, o enfrentamento dos riscos e a construção de alternativas pressupõem que a maioria dos professores coloque "sub judice" algumas "certezas profissionais", algumas concepções cristalizadas, oriundas quer da sua formação quer da cultura da escola:

O sucesso dessas atividades provocou um sentimento de satisfação no grupo, mostrando que "dá pra fazer diferente". Para isso fomos explicitando, discutindo e reavaliando certos conceitos preconcebidos, que muitas vezes ficam implícitos.

Ao mesmo tempo, é fácil identificar que os procedimentos elaborados não são inéditos nem sofisticados, razão pela qual considerei desnecessário 
detalhá-los neste artigo. Certamente estão presentes em projetos de muitas escolas. Entretanto, eles implicaram um conjunto articulado de propostas de transformação de um saber-fazer, não são um "pacote" a ser executado ou "vendido".

Preciso também reconhecer que a presença de uma liderança qualificada é decisiva nesse processo - foi fundamental a participação no projeto tanto de professoras bem-sucedidas e experientes no ensino fundamental quanto dos próprios pesquisadores para que as alternativas fossem pensadas e construídas. Havia um norte teórico claramente presente: não reduzimos o desafio a mero exercício de tentativa e erro, de refletir por refletir, ou para facilitar e agradar os alunos com tarefas lúdicas. Trata-se de processo com intencionalidade explícita, que dirige e avalia todas as decisões e procedimentos. Decisivo foi o papel dos pesquisadores quando os resultados não foram os esperados, quando preconceitos e estereótipos vieram à tona, ou sobretudo quando se tentou negligenciar a finalidade da escola.

Assim, considero que todo esse processo de reinterpretar os conceitos cristalizados na sabedoria docente foi o passo prévio e decisivo para que um projeto alternativo de trabalho educativo fosse concretizado. Todo esse trabalho bem-sucedido não foi repetido na mesma escola no ano seguinte devido à rotatividade dos professores (problema fulcral nas escolas públicas brasileiras de periferia), apesar da insistência de duas das professoras que haviam participado do projeto e que permaneceram na escola (apenas duas) e do impacto que os "livrinhos" tiveram sobre a comunidade escolar. Eis aí um entrave decisivo para transformação de nossas escolas públicas, como problematizamos desde a década de oitenta:

A itinerância e rotatividade dos professores nas escolas públicas não é meramente um problema administrativo, mas é sobretudo um comprometedor pedagógico, já que:

- impede o envolvimento do professor com a escola, seu conhecimento dos espaços disponíveis e sobretudo do desenvolvimento de seus alunos e comunidade (que cada vez mais frequentemente sequer sabem o nome dos professores);

- dificulta que a própria escola tenha um corpo docente definido e comprometido com um projeto, chegando ao extremo de inviabilizar o planejamento escolar - já que a direção sequer sabe com quem poderá contar no ano seguinte;

- compromete a continuidade do processo de ensino - já que em anos consecutivos (ou até em meses) os alunos convivem com professores diferentes e propostas de trabalho raramente concretizadas sequencialmente;

- penaliza as pequenas escolas ou as de condições mais precárias, justamente as que necessitariam de um maior esforço de transformação, já que elas são sempre as primeiras a serem "abandonadas" no processo de troca de professores;

- $\quad$ altera a própria rotina de vida pessoal do professsor - que muitas vezes gasta grande parte do tempo e salário se deslocando de bairro em bairro, gerando uma situação constante de stress: o "cansaço" presente no trabalho no período noturno. (Dias-da-Silva, Chakur, 1990, p. 32) 
Apesar de se revelar estéril na escola em que foi gerado, por outro lado, felizmente, vários dos professores que participaram desse projeto propuseram esse caminho no ano seguinte para a $5^{a}$ série em outras escolas, algumas até em outras cidades.

Vale registrar o depoimento de uma professora sobre o que ouviu em outra escola, explicitando claramente a "sabedoria" cristalizada: "não faz o menor sentido abrir os braços para os alunos desse jeito, depois, eles montam em cima da gente!" Já em outra cidade, um professor conseguiu envolver seu grupo de colegas que, entusiasmados, estudaram a tese, discutiram as atividades e organizaram o "livrinho" com seus alunos nas diferentes disciplinas.

Apesar de episódicos, esses são exemplos claros de que não se trata de "vender um pacote" ou "implantar uma proposta de trabalho". Fundamentos diferentes geram ações diferentes. Apenas um pensar alternativo, com outros óculos, permite um agir diferenciado. Saberes e fazeres - articulados. Conjuntos: ação e pensamento, ação e organização norteados por uma intencionalidade fundada no conhecimento educacional.

Nossos resultados sugerem que analisar a sabedoria docente com os professores e problematizá-la, incluindo contribuições teóricas e de pesquisa, são passos imprescindíveis para enfrentar os dilemas profissionais docentes, enfrentamento que pressupõe respeitar os professores, suas experiências e crenças, mesmo aquelas cristalizadas na cultura das escolas. Ressignificar a realidade é, decididamente, passo prévio para transformá-la e, talvez com isso, melhorar nossas escolas e nossa sociedade.

\section{Referências bibliográficas}

ANDRÉ, Marli Eliza Dalmazo Afonso de. Formação de professores em serviço: um diálogo com vários textos. Cadernos de Pesquisa, São Paulo, n. 89, p.72-75, 1994.

Etnografia da prática escolar. Campinas: Papirus, 1995.

AZANHA, José Mário Pires. Educação: alguns escritos. São Paulo: Companhia Editora Nacional, 1987.

BARROSO, João. Fazer da escola um projeto. In: CANARIO, Rui. Inovação e projeto educativo de escola. Lisboa: Educa, 1992.

CARVAlHO, Marília Pinto de. Entre a casa e a escola: educadoras de primeiro grau na periferia de São Paulo. Revista Brasileira de Estudos Pedagógicos, Brasília, v. 76, n. 184, p. 407-444, set./dez. 1995. 
CUNHA, Maria Isabel da. O bom professor e sua prática. Campinas: Papirus, 1989.

DIAS-DA-SILVA, Maria Helena Galvão Frem. O professor e seu desenvolvimento profissional: superando a concepção de algoz incompetente. Cadernos Cedes, v. 19, n. 44, p. 33-45, 1998.

. Passagem sem rito: os professores e as quintas séries. Campinas: Papirus, 1997.

. Sabedoria docente: repensando a prática pedagógica. Cadernos de Pesquisa, n. 89, p. 39-47, 1994.

DIAS-DA-SILVA, Maria Helena G. Frem; CHAKUR, Cilene Ribeiro de Sá Leite. O ensino de $5^{\mathrm{a}}$ a $8^{\mathrm{a}}$ série: pistas para compreensão da escola pública. Boletim do Departamento de Didática [A situação de ensinar e aprender], Araraquara, v. 9, n. 6, p. 29-39, 1990.

ELLIOTT, John. Recolocando a pesquisa-ação em seu lugar original e próprio. In: GERALDI, Corinta Maria Grisolia et al. (Orgs.). Cartografias do trabalho docente: professor(a)-pesquisador(a). Campinas: Mercado de Letras, 1998.

FRIGOTTO, Gaudêncio. Educação e a crise do capitalismo real. São Paulo: Cortez, 1995.

FULLAN, Michel; HARGREAVES, Andy. Teacher development and educational change. London: The Falmer Press, 1992.

GIMENO SACRISTÁN, José. Consciência e acção sobre a prática como libertação profissional dos professores. In: NÓVOA, Antonio (Org.). Profissão: professor. Porto: Porto Ed., 1991.

GIROUX, Henry A. Os professores como intelectuais: rumo a uma pedagogia crítica da aprendizagem. Porto Alegre: Artes Médicas, 1997.

MARIN, Alda Junqueira et al. Desenvolvimento profissional docente e transformações na escola. Revista Pro-Posições, Campinas, v. 11, n. 1(31), p. 14-25, mar. 2000. Disponível em: <www.proposicoes. fe.unicamp.br/ proposicoes/textos/31_artigo_marinajetal.pdf $>$.

MINE, J. C. P.; DIAS-DA-SILVA, Maria Helena G. Frem. As preferências e expectativas dos alunos de $5^{\text {a }}$ série: a importância do trabalho docente. In: ENCONTRO NACIONAL DE DIDÁTICA E PRÁTICA DE ENSINO (Endipe). Anais... Lindóia, 1998. p. 508.

NÓvOA, Antonio (Org.). Profissão professor. Porto: Porto Ed., 1991. 
NÓVOA, Antonio (Org.). Os professores e sua formação. Lisboa: Dom Quixote, 1992a.

. (Org.). Vidas de professores. Porto: Porto Ed., 1992b.

PEREIRA, João Batista Borges. A escola secundária numa sociedade em mudança. São Paulo: Pioneira Editora, 1968.

SAMPAIO, M. M. F. Um gosto amargo de escola: relações entre currículo, ensino e fracasso escolar. São Paulo: Educ/Fapesp, 1998.

SANDERS, D. P.; McCUTCHEON, G. The development of practical theories of teaching. Journal of Curriculum and Supervision, v. 2, n. 1, p. 50-67, 1986.

SÃO PAULO. Secretaria Municipal de Educação. Problematização da escola: a visão dos educandos. São Paulo, 1991.

SCHLECHTY, P. C.; WHITFORD, B. L. Shared problems and shared vision: organic collaboration. In: SIROTNIK, K. A.; GOODLAD, J. I. (Org.). School-university partnerships in action: concepts, cases and concerns. New York: Teachers College Press, 1988.

SEVERINO, Antonio Joaquim. A escola de primeiro grau: organização e funcionamento. Caderno Idéias, n. 11, p. 59-69, 1991.

SPÓSITO, Marília Pontes. O povo vai à escola. São Paulo: Loyola, 1984.

TIBA, Içami. Disciplina: limite na medida certa. São Paulo: Gente, 1996.

TRUZZI, E. D.; DIAS-DA-SILVA, Maria Helena G. Frem. As dificuldades e as falsas ameaças: as expectativas dos alunos frente às $5^{\text {as }}$. séries. In: ENCONTRO NACIONAL DE DIDÁTICA E PRÁTICA DE ENSINO (Endipe). Anais.... Lindóia, 1998. p. 500-501.

VEIGA, I. P. A. (Org.). Escola: espaço do projeto pedagógico. Campinas: Papirus, 1998.

ZEICHNER, Kenneth M. A formação reflexiva de professores: ideias e práticas. Lisboa: Educa, 1993. 
Maria Helena G. Frem Dias-da-Silva, doutora em Educação pela Faculdade de Educação da Universidade de São Paulo (USP), com pós-doutorado na Universidade de Pittsburgh (USA), é professora assistente do Departamento de Didática e docente do Programa de Pós-Graduação em Educação Escolar da Universidade Estadual Paulista Júlio de Mesquita Filho (Unesp), campus de Araraquara.

malena@fclar.unesp.br

Recebido em 25 de março de 2011.

Aprovado em 11 de julho de 2011. 